\title{
Effect of Partial Substitution of Raw Gypsum with Thermally Treated Phosphogypsum on the Properties of Portland Pozzolanic Cement
}

\author{
Mahmoud Ahmed Taher ${ }^{\mathrm{a}}$, Adel Mohamed Amine ${ }^{\mathrm{b}}$, Bassam Khalaf Damarany ${ }^{\mathrm{c}, *}$ \\ a Chemistry Department, Faculty of Science, Al-Azhar University, Assiut, Egypt \\ ${ }^{b}$ Housing and Building National Research Center, Cairo, Egypt \\ ${ }^{c}$ Manaseer Cement and Mining Company, Amman, Jordan
}

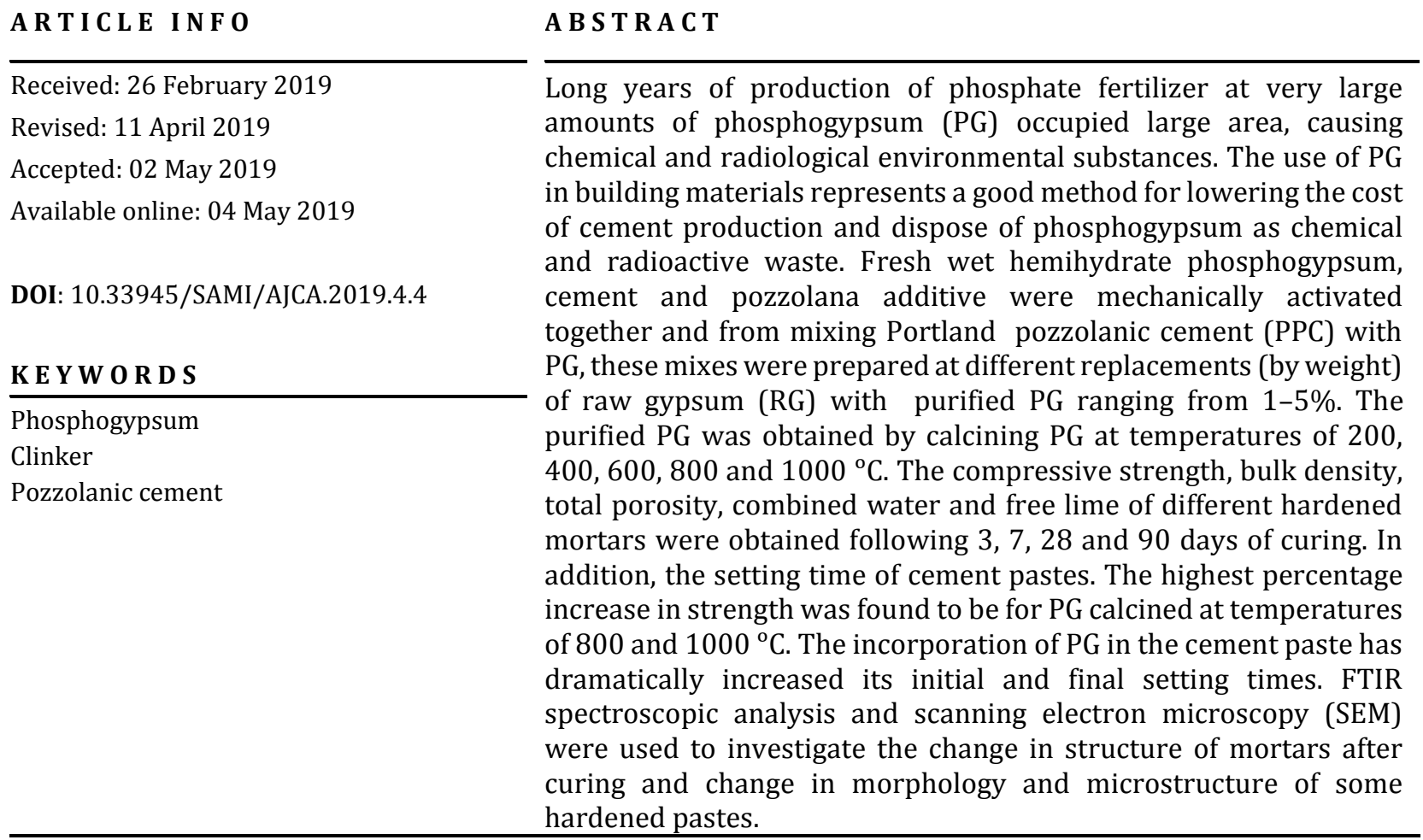

G R A P H I C A L A B S T R A C T
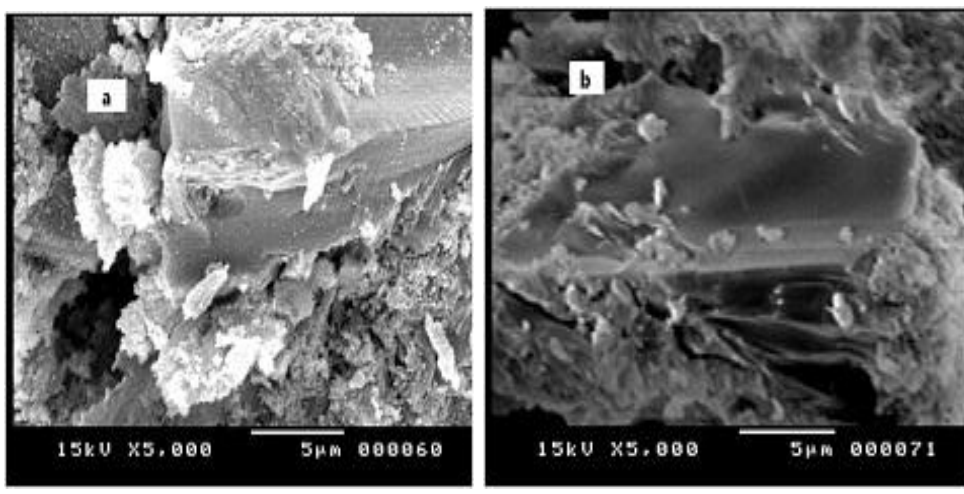

Micrographs of mixes (PPV) contain thermally treatment PG at $600{ }^{\circ} \mathrm{C}$ after 3(a), 28 (b) and 90 (c) days curing

\footnotetext{
* Corresponding author's E-mail address:

Ch_bassam66@yahoo.com
} 


\section{Introduction}

The quantity of $\mathrm{PG}$ produced is very large: for each 1 ton of phosphate $\left(\mathrm{P}_{2} \mathrm{O}_{5}\right)$ produced, there is a coproduction of 5 tons of calcium sulfate (PG). The annual world production of this material is up to 180 million tons and is expected to reach up to 300 million tons by the year 2000 [1]. Only $15 \%$ of the PG is utilized by the cement and gypsum industries as a setting moderator for cement and for making gypsum plaster. The impurities in PG have been found to delay the setting time and reduce the rate of early strength development of cement to a greater extent than pure gypsum, although strengths at later ages are not affected. Fortunately, either chemical processing or heat treatment can reduce these impurities. The remaining $85 \%$ of $P G$ is not used, causing an environmental problem and creating need for large areas for disposal. Therefore, attempts were made to use PG in applications such as road and rail works fills, stabilization of base course, and building constructions. In addition, the potential for using PG in making roller-compacted concrete [2-9]. Smadi, Haddad and Akour studied utilization of phosphogypsum as cement (OPC and PPC) replacement agents in mortars and found decrease in compressive strength. The incorporation of phosphogypsum in the cement has drastically increased its initial strength. Also, this strength development was attributed to formation of anhydrate at higher temperatures [10]. Treated phosphogypsum can be used as an ingredient of plaster [1113]. The most important and motivating use of phosphogypsum could be in the construction industry. In the manufacturing process of cement, phosphogypsum could be used as a replacement of natural gypsum which plays the role of a set retarder $[14,15]$ on the other hand. Bagade et al., studied the partial replacement of cement by various percentage of phosphogypsum gave good result with concrete specimens [16]. Researches $[17,18]$ on the basic engineering properties of phosphogypsum-based concrete mixtures concluded that the unique properties of dehydrate phosphogypsum under compaction-consolidation can significantly contribute to the compressive strength of concrete mixes. However, with higher percentage of phosphogypsum, the strength of concrete mixtures is affected by the moisture at the time of testing. Better compressive strength attained with calcined phosphogypsum [19]. Reddya et al., studied the replacement cement by phosphogypsum and they have found the replacement at $10 \%$ act optimum [20]. At present, phosphogypsum is mainly used in building materials industry, including cement retarder, building gypsum powder, gypsum board, exterior gypsum board, fiber plaster board, mine filling agent and road bed material [21]. However, prospective processes for largescale utilization of phosphogypsum are still under investigation. The utilization of phosphogypsum is realistically a significant problem in phosphoric acid industry [22]. AlJabbari et al., [8] adopted a physical method for the purification of $P G$ prior to using it as a building material. The method consists of washing PG with water using sieve no. $100 \mu$, burning the PG at different temperatures (low and high), and adding some accelerators (such as calcium hydroxide) to the calcined PG in order to improve the setting time and the compressive strength of the produced material. The purified PG was analyzed chemically and tested physically. The results indicated that the best and cheapest method for the purification of PG was through washing with water, then neutralizing with calcium hydroxide. Roy et al., [23] studied the potential of using a by-product slag, produced by sulfur-recovery process from $\mathrm{PG}$, as an aggregate in Portland cement concrete. The phase composition and microstructure of two different samples of produced slag were studied. The study showed that although both 
slags have different microstructure, mineralogically both are suitable as aggregate in concrete as long as the amount of sulfate is not too high (4.5\%).

\section{Experimental}

Materials

In this study, the clinker used in the present experimental study has been obtained from Manaseer Cement Company (Jordan), The Clinker was procured from local market. Phosphogypsum (PG) are produced as by-products of phosphoric acid manufacture process in Jordan Abyad Fertilizers and Chemicals Company (Jordan). Millions tons from PG wastes are stockpiled over open areas. Major negative environmental impacts are highly expected due to dissolution of various hazardous chemicals the stockpiled contains. Its chemical composition and mineralogical constituents are illustrated in Table 1. Raw Gypsum (RG) is one of the non-metallic minerals, composed mainly of hydrated calcium sulfate. It is usually formed by precipitation of $\mathrm{CaSO}_{4} \cdot 2 \mathrm{H}_{2} \mathrm{O}$ due to evaporation of solution with high content of $\mathrm{SO}_{4}{ }^{2-}$ and $\mathrm{Ca}^{2+}$ ions. Finally, Pozzolana (Pz) Tuff as pozzolanic material was obtained from Tal-Hassan which is located about $120 \mathrm{~km}$ northeast of Jordan. Portland Pozzolanic Cement (PPC) was prepared by mixing $70 \%$ from clinker, $25 \%$ pozzolana and 5\% from raw gypsum. Several pastes were made in this investigation by partial substitution of raw gypsum with thermally treated phosphogypsum at different temperatures 200, 400, 600,800 and $1000^{\circ} \mathrm{C}$ at different proportions Table 2. The initial water/solid ratio used in this study were varied from 0.3-0.5 according to the amount of replaced thermally treated phosphogypsum.

Table 1. The chemical compositions (\%) of the raw materials

\begin{tabular}{|c|c|c|c|c|c|c|c|c|c|}
\hline Contents & PCC & $\begin{array}{l}\text { PG before } \\
\text { Firing }\end{array}$ & $\begin{array}{c}\mathrm{PG} \text { at } \\
200{ }^{\circ} \mathrm{C}\end{array}$ & $\begin{array}{l}\mathrm{PG} \text { at } \\
400{ }^{\circ} \mathrm{C}\end{array}$ & $\begin{array}{l}\mathrm{PG} \text { at } \\
600{ }^{\circ} \mathrm{C}\end{array}$ & $\begin{array}{c}\mathrm{PG} \text { at } \\
800{ }^{\circ} \mathrm{C}\end{array}$ & $\begin{array}{c}\text { PG at } \\
1000{ }^{\circ} \mathrm{C}\end{array}$ & $\mathrm{RG}$ & $\mathrm{Pz}$ \\
\hline $\mathrm{CaO} \%$ & 64.48 & 35 & 35.12 & 35.8 & 36.71 & 37.5 & 40.53 & 39.82 & 10.61 \\
\hline $\mathrm{SiO} 2 \%$ & 21.32 & 8.32 & 8.48 & 8.56 & 9.07 & 9.50 & 10.52 & 6.81 & 41.23 \\
\hline $\mathrm{AL}_{2} \mathrm{O}_{3} \%$ & 5.32 & 0.15 & 0.16 & 0.33 & 0.56 & 0.29 & 0.25 & 1.1 & 12.15 \\
\hline $\mathrm{Fe}_{2} \mathrm{O}_{3} \%$ & 3.78 & 0.17 & 0.15 & 0.2 & 0.16 & 0.16 & 0.15 & 0.56 & 15.41 \\
\hline MgO \% & 2.08 & 0.42 & 0.42 & 0.45 & 0.47 & 0.482 & 0.2 & 1.59 & 8.78 \\
\hline $\mathrm{K}_{2} \mathrm{O} \%$ & 0.58 & 0.04 & 0.04 & 0.04 & 0.036 & 0.043 & 0.003 & 0.35 & 2.07 \\
\hline $\mathrm{Na}_{2} \mathrm{O} \%$ & 0.58 & $\ldots$. & 0.1 & $\ldots .$. & $\ldots .$. & $\ldots .$. & 0.74 & 0.01 & 4.62 \\
\hline SO3 \% & 0.89 & 42.06 & 39 & 35.32 & 33.63 & 36.21 & 33.1 & 22.18 & 0.098 \\
\hline $\mathrm{P}_{2} \mathrm{O}_{5} \%$ & 0.33 & 6.79 & 6.44 & 3.94 & 3.77 & 2.55 & 2.35 & 0.39 & 0.74 \\
\hline CL \% & 0.002 & $\ldots .$. & 0.01 & $\ldots$ & 0.28 & 0.34 & 0.43 & 0.02 & 0.003 \\
\hline LOI \% & 0.00 & 10.1 & 9.63 & 7.43 & 3.6 & 1.01 & 0.82 & 31.04 & 0.96 \\
\hline $\mathrm{Cr}_{2} \mathrm{O}_{3} \%$ & 0.011 & $\ldots$ & $\ldots$ & $\ldots .$. & $\ldots$ & $\ldots$ & $\ldots$ & $\ldots .$. & 0.087 \\
\hline $\mathrm{TiO}_{2} \%$ & 0.56 & 0.054 & 0.056 & 0.054 & 0.052 & 0.047 & 0.052 & 0.12 & 4.14 \\
\hline $\mathrm{Mn}_{2} \mathrm{O}_{3} \%$ & 0.022 & $\ldots$ & $\ldots .$. & $\ldots$ & $\ldots$ & $\ldots$ & $\ldots$ & $\ldots \ldots$ & 0.27 \\
\hline $\mathrm{ZnO} \%$ & 0.000 & 0.045 & 0.015 & 0.045 & 0.048 & 0.037 & 0.018 & 0.008 & 0.025 \\
\hline $\mathrm{SrO} \%$ & 0.045 & 0.46 & 0.29 & 0.52 & 0.55 & 0.47 & 0.333 & 0.35 & $\ldots .$. \\
\hline
\end{tabular}


Table 2. The mix composition of PPC pastes made by partial substitution of RG with thermally treated $P G$ at different temperatures

\begin{tabular}{cc} 
Mix No & Composition of Mixes \\
PPC & $70 \%$ clinker $+5 \%$ RG $+25 \% \mathrm{Pz}$ \\
PPI & $70 \%$ clinker $+4 \%$ RG $+1 \%$ PG $+25 \% \mathrm{Pz}$ \\
PPII & $70 \%$ clinker $+3 \% \mathrm{RG}+2 \% \mathrm{PG}+25 \% \mathrm{Pz}$ \\
PPIII & $70 \%$ clinker $+2 \% \mathrm{RG}+3 \% \mathrm{PG}+25 \% \mathrm{Pz}$ \\
PPIV & $70 \%$ clinker $+1 \% \mathrm{RG}+4 \% \mathrm{PG}+25 \% \mathrm{Pz}$ \\
PPV & $70 \%$ clinker $+5 \% \mathrm{PG}+25 \% \mathrm{Pz}$ \\
\hline RG: Raw Gypsum & PG: Phosphogypsum
\end{tabular}

\section{Methods and Instruments}

The mixes (PPI-PPV) were prepared by mixing thermally treated phosphogypsum at different temperatures $200,400,600,800$ and $1000{ }^{\circ} \mathrm{C}$ at different portions with clinker and raw gypsum. The thermal treated of PG has been done by heating $2 \mathrm{~h}$ $\left(10{ }^{\circ} \mathrm{C} / \mathrm{min}\right)$ in muffle furnace for the required temperatures. PG was cooled in room temperature after every calcined temperature then crushed and ground in jaw crusher machine. The chemical composition and mineralogical constituents of Portland Cement Clinker (PCC), Phosphogypsum (PG), and Raw Gypsum (RG), are illustrated in Table 1 by XRF 9900, all these material were separately crushed and ground in the jaw crusher machine. The ingredients of each mix blended in the lab ball mill for $2 \mathrm{~h}$ to insure complete homogeneity. Specimens were cast into mold of $\left(2.54^{*} 2.54 \mathrm{~cm}\right)$, then the specimens in the mold were stored curing in humidity chamber at $20 \pm 1^{\circ} \mathrm{C}$ for $24 \mathrm{~h}$. then demolded and immersed in tap water until tested. After the predetermined curing time 3, 7, 28 and 90 days, groups of three specimens were used to determine the residual compressive strength. Setting times of cement mixed by mixing different proportions were measured by Vicat apparatus according to EN-196-3 [24]. Bulk density and total porosity were determined after any time of hydration as described elsewhere [25]. The hydration of cement pastes were stopped by employing alcoholether method [26]. The samples were dried at $105{ }^{\circ} \mathrm{C}$ for $1 \mathrm{~h}$ and then collated in polyethylene bags; sealed and stored in desiccators for analysis. The degree of hydration was followed by determination of free lime [26] and chemically combined water content [27]. On the other hand, the raw materials characterized by XRF (Fluorescence (XRF Thermo Scientific ARL 9900 Total Cement Analyzer) and the change in structure of mortars after curing characterize by FTIR spectroscopic (a Perkin-Elmer System $2000 \quad$ FTIR spectrometer) and scanning electron microscopy SEM (JEOL JSM-840 SEM) were used for investigate and change in morphology and microstructure of some hardened pastes, finally the compressive strength of hardened pastes determined by the digital compressive strength machine (Toni/ technik).

\section{Results and Discussion}

\section{Setting time and water consistency}

Normal setting of cement is associated with the hydration of Alite (impure C3S) and formation of the calcium silicate hydrate (CSH) phase. On the contract, the initial and final setting time pasts PPC- PG treated at $200,400,600,800$ and $1000{ }^{\circ} \mathrm{C}$ increases 
with increasing the substitution of RG with $P G$ and decreased by increasing treatment temperature of $\mathrm{PG}$, the reasons of all these results are attributed to thermal treatment of $P G$ which decrease the pronounced effect of water soluble $\mathrm{P}_{2} \mathrm{O}_{5}$ and present phosphorus, sulfate, fluoride, and organic impurities contained in $\mathrm{PG}$ interfere in an unpredictable way to delay the setting time in PG [11]. Form protective coating as by the impurities on the surface of cement grains during the gauging of cement with water and thus suppression of the hydration of cement temporarily [30]. In general, the setting time decreasing with increasing temperature, hence, OPC containing PG treated at $800{ }^{\circ} \mathrm{C}$ and $1000{ }^{\circ} \mathrm{C}$ have lowest setting time. The water/cement ratio $\mathrm{W} / \mathrm{C}$ of hardened specimens made from PPC-PG with treatment at $200{ }^{\circ} \mathrm{C}$ decreases by increasing the amount of PG gradually from $24.4 \%$ (PPI) to $23.4 \%$ (PPV) respectively, by increasing firing temperature of $P G$ the water/cement ratio $\mathrm{W} / \mathrm{C}$ decreases this may be anhydrite higher water demand. The specimens from PPC-PG fired at $800{ }^{\circ} \mathrm{C}$ and $1000{ }^{\circ} \mathrm{C}$ possess the lowest water of consistency value $23 \%$. Hence, by increasing firing temperature the water/cement ratio decreases.

Compressive strength
The compressive strength of cement mortar is considered to be one of the most important aspects of Pozzolanic Portland cement. Five representative mixes were chosen to study the influence of the replacement PG (at different temperatures) on the compressive strength. Figures 1-5 showed the relation between compressive strength and curing time at different percentage of $P G$, the trend of the strength increases by curing time, therefore, the pastes of hardened made from PPC and PG treated at $1000{ }^{\circ} \mathrm{C}$ have strength at $3,7,28$, 90 days higher than blank sample. It was clear that, compressive strength values increased by increase the firing temperature, this is due to calcinations of lime presence in $\mathrm{PG}$ at $1000{ }^{\circ} \mathrm{C}$ which causes development in the strength and the strength depends primarily on the formation of hydrated calcium silicate as the main hydration product, which is precipitated into the water filled spaces to form a more compact body. This is mainly attributed to crystallization of the initially formed hydrates, having strong binding forces and/or their transformation into other hydration products having weaker binding forces. Finally, Mix PPV containing $5 \%$ thermally treated $\mathrm{PG}$ at $1000{ }^{\circ} \mathrm{C}$ possesses the highest compressive strength value after 90 days curing.

Table 3. Setting time from mixes (PPC-PPV) containing thermally treated PG at different temperature

\begin{tabular}{|c|c|c|c|c|c|c|c|c|c|c|}
\hline \multirow[b]{2}{*}{ Mix } & \multicolumn{2}{|c|}{$200{ }^{\circ} \mathrm{C}$} & \multicolumn{2}{|c|}{$400^{\circ} \mathrm{C}$} & \multicolumn{2}{|c|}{$600^{\circ} \mathrm{C}$} & \multicolumn{2}{|c|}{$800^{\circ} \mathrm{C}$} & \multicolumn{2}{|c|}{$100^{\circ} \mathrm{C}$} \\
\hline & $\begin{array}{l}\text { Initial } \\
\text { (min) }\end{array}$ & $\begin{array}{l}\text { Final } \\
\text { (min) }\end{array}$ & $\begin{array}{l}\text { Initial } \\
\text { (min) }\end{array}$ & $\begin{array}{l}\text { Final } \\
\text { (min) }\end{array}$ & $\begin{array}{l}\text { Initial } \\
\text { (min) }\end{array}$ & $\begin{array}{l}\text { Final } \\
\text { (min) }\end{array}$ & $\begin{array}{l}\text { Initial } \\
\text { (min) }\end{array}$ & $\begin{array}{l}\text { Final } \\
\text { (min) }\end{array}$ & $\begin{array}{l}\text { Initial } \\
\text { (min) }\end{array}$ & $\begin{array}{l}\text { Final } \\
\text { (min) }\end{array}$ \\
\hline PPI & 335 & 425 & 350 & 430 & 330 & 440 & 200 & 285 & 180 & 265 \\
\hline PPII & 460 & 600 & 560 & 640 & 610 & 730 & 205 & 290 & 190 & 270 \\
\hline PPIII & 720 & 840 & 630 & 720 & 740 & 810 & 220 & 310 & 200 & 270 \\
\hline PPIV & 780 & 860 & 680 & 740 & 750 & 815 & 215 & 275 & 205 & 280 \\
\hline PPV & 730 & 810 & 715 & 830 & 605 & 700 & 210 & 300 & 200 & 265 \\
\hline PPC & 185 & 255 & & & & & & & & \\
\hline
\end{tabular}




\section{Bulk density and total porosity}

Figures 6-10 illustrated the bulk density of the hardened pastes containing calcined PG at different temperatures as a function of curing time. Clearly, at different temperature the bulk density increases with longer hydration time for all samples, so the results of the bulk density progress at 90 days it's highest. On the contract, the compressive strength increases with decreases the total porosity, so when the compressive strength increases the total porosity decreases [28] and increases the bulk density this is due to hydration products fill parts of the total pore volumes. Porosity can govern the properties of the materials, especially affecting material strength. High porosity will result in low material strength, whereas decreasing porosity can enhance material strength [29]. The results in Figures 11-15 indicate that the total porosity for all samples PPC contain firing PG at different temperature decrease gradually for long time, the results for all samples possess higher porosity at 3 days, on the other hand the lowest total porosity at 90 days [30]. Generally, the results show that for all pastes at all ages, the porosity decreased as the curing age increased, this is due to the filling up of a part of the available pore volume with the hydration products, as the hydration proceeds.

\section{Chemically combined water content (\%)}

According to Figures 16-20 the chemically combined water content of hardened specimens made from PPC which contain PG treated at 200, 400, 600, 800 and $1000{ }^{\circ} \mathrm{C}$ increases by increasing curing time, the results of hydration kinetics indicated that chemically-combined water contents increases with increasing age of hydration for all types of hardened PPC-PG pastes. Mix PPI (70\% PCC: 25\% Poz: 4\% RG: 1\% PG treated at $200{ }^{\circ} \mathrm{C}$ ) possesses higher combined water content values, while mixes PPIV and PPV (which contain PG treated at $1000{ }^{\circ} \mathrm{C}$ ) possesses the lowest values. These results are in harmony with that obtained with respect to the compressive strength, bulk density and porosity results which indicated that mixes PPIV and PPV at $1000{ }^{\circ} \mathrm{C}$ have the highest values.
Figure 1. Compressive strength of hardened pastes made from mixes (PPC-PPV) containing thermally treated $P G$ at $200{ }^{\circ} \mathrm{C}$ after $3,7,28$ and 90 days curing

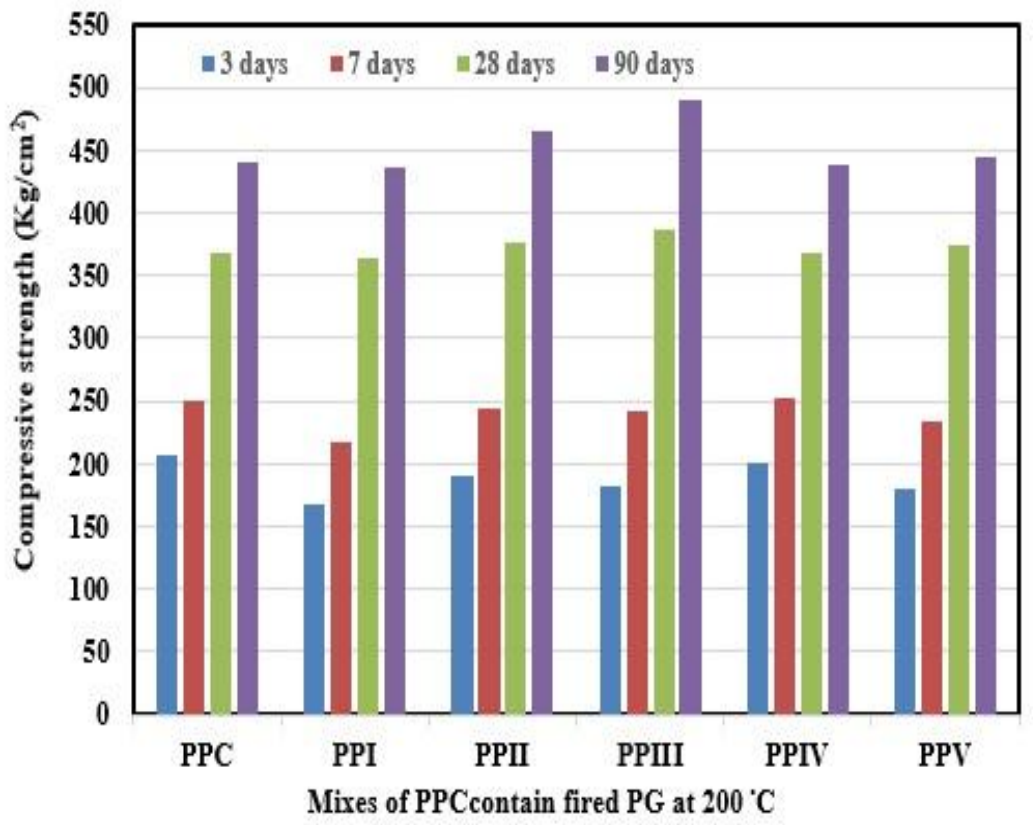

Adv J Chem A 2019, 2(4), 296-315 
Figure 2. Compressive strength of hardened pastes made from mixes (PPC-PPV) containing thermally treated PG at $400{ }^{\circ} \mathrm{C}$ after $3,7,28$ and 90 days curing

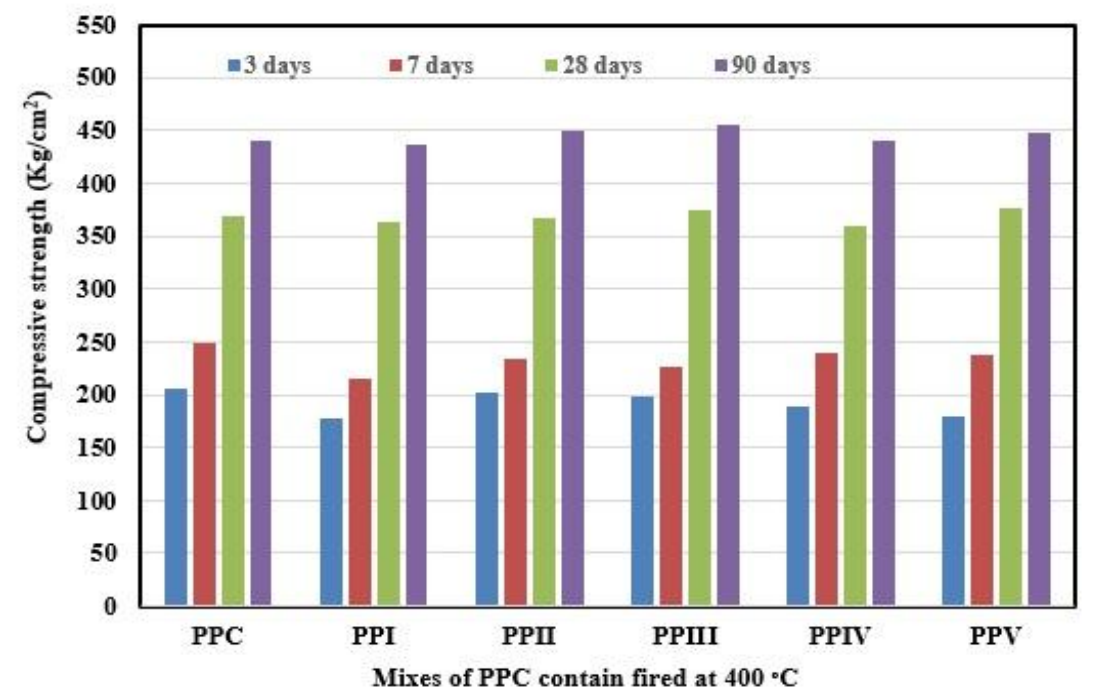

Figure 3. Compressive strength of hardened pastes made from mixes (PPC-PPV) containing thermally treated PG at $600{ }^{\circ} \mathrm{C}$ after 3, 7, 28 and 90 days curing

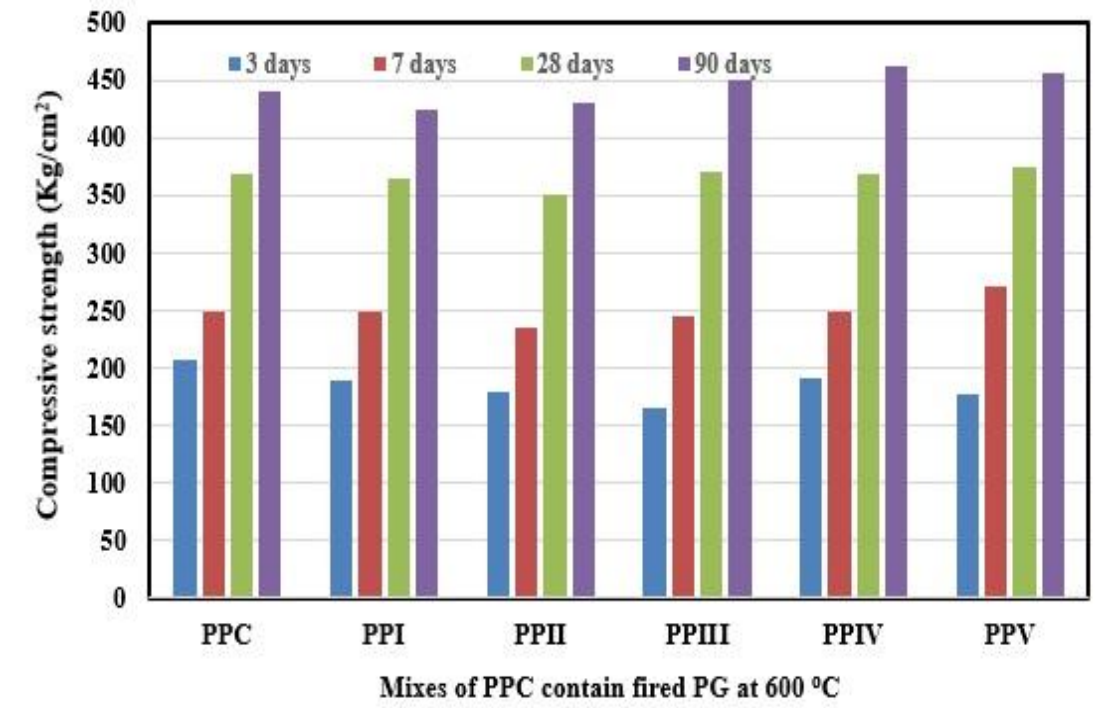

Figure 4. Compressive strength of hardened pastes made from mixes (PPC-PPV) containing thermally treated PG at $800{ }^{\circ} \mathrm{C}$ after 3, 7, 28 and 90 days curing

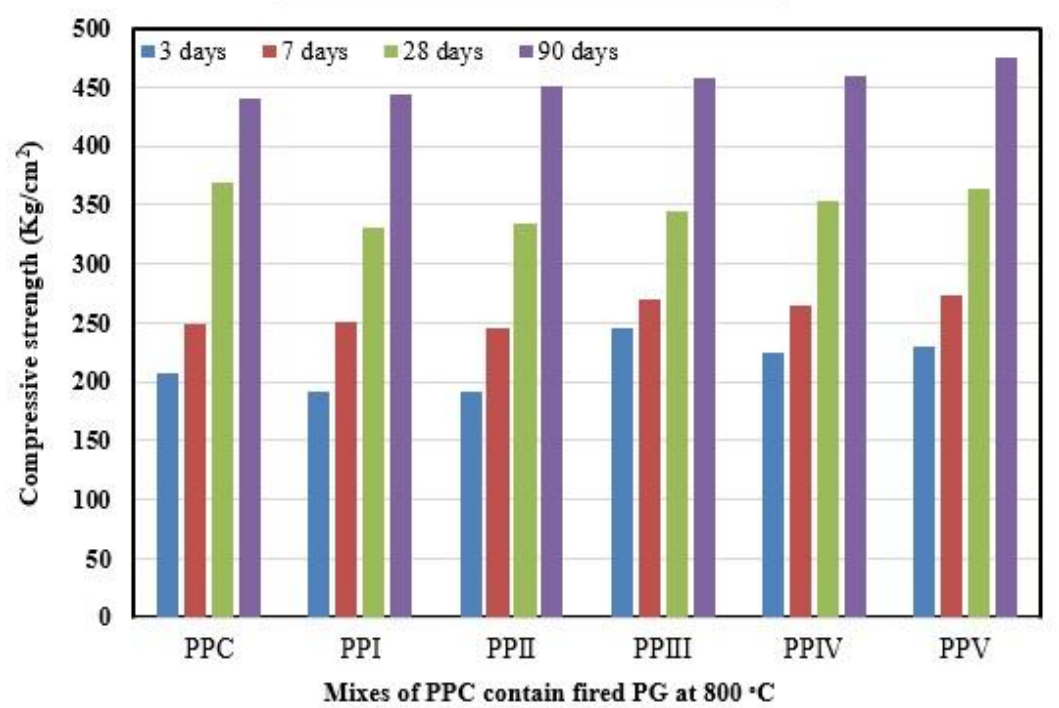


Figure 5. Compressive strength of hardened pastes made from mixes (PPC-PPV) containing

thermally treated $\mathrm{PG}$ at $1000{ }^{\circ} \mathrm{C}$ after $3,7,28$ and 90 days curing

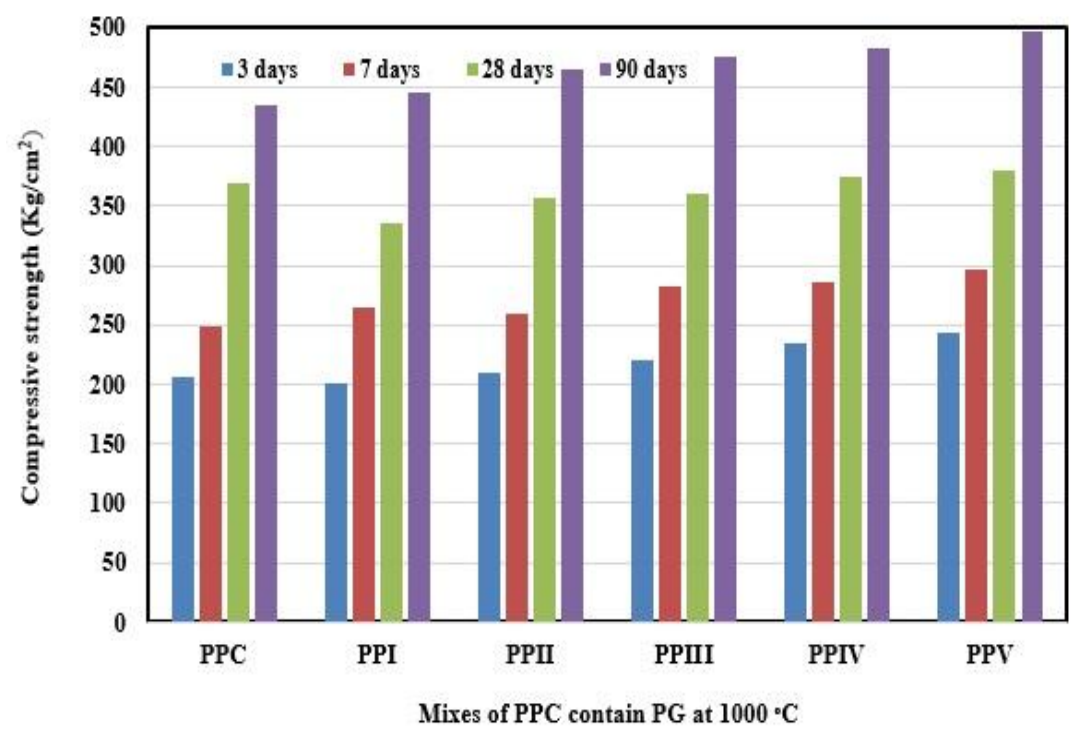

Figure 6. Bulk density $\left(\mathrm{g} / \mathrm{cm}^{3}\right) \quad$ hardened pastes made from mixes (PPC-PPV) containing

thermally treated $P G$ at $200^{\circ} \mathrm{C}$ after $3,7,28$ and 90 days curing

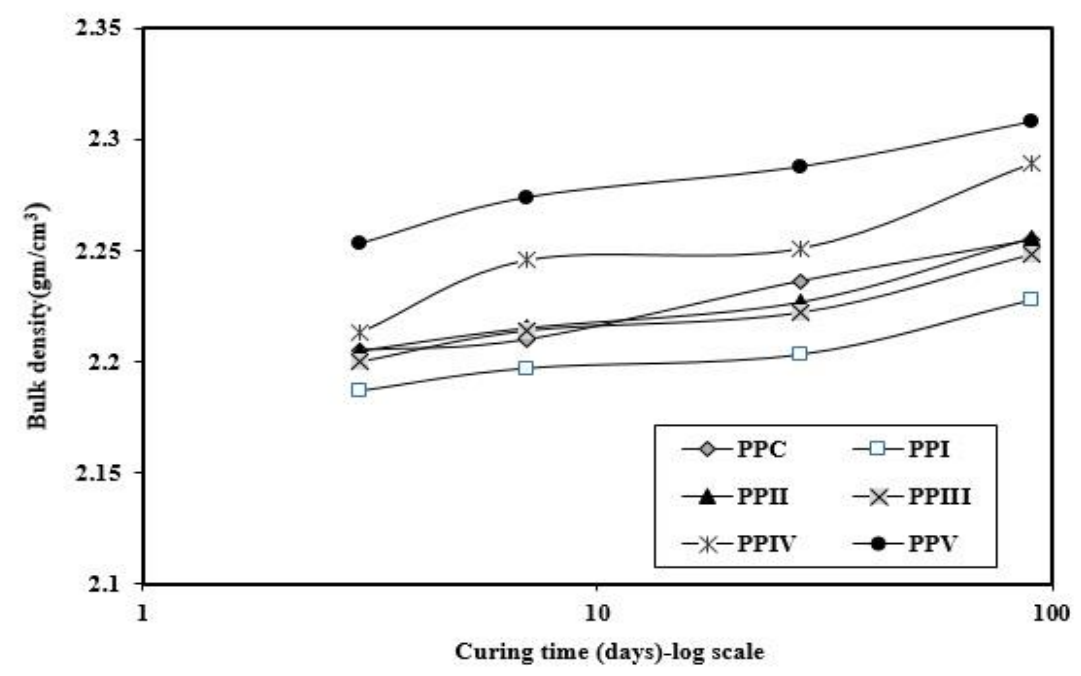

Figure 7. Bulk density $\left(\mathrm{g} / \mathrm{cm}^{3}\right) \quad$ hardened pastes made from mixes (PPC-PPV) containing thermally treated $\mathrm{PG}$ at $400{ }^{\circ} \mathrm{C}$ after 3, 7, 28 and 90 days curing

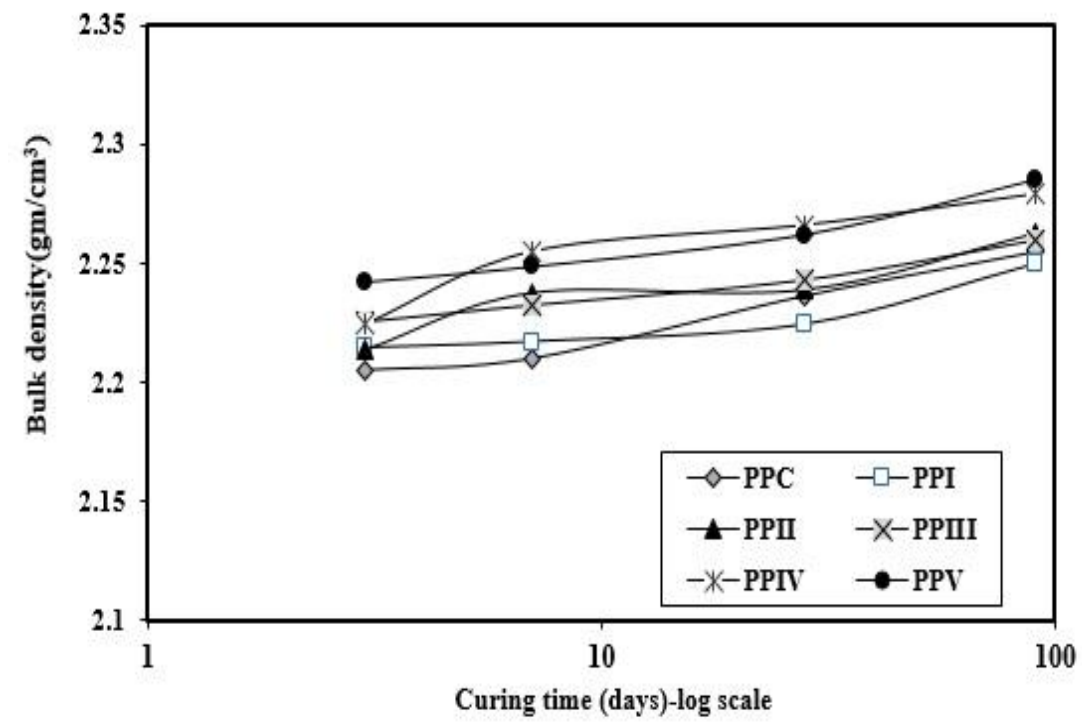


Figure 8. Bulk density $\left(\mathrm{g} / \mathrm{cm}^{3}\right) \quad$ hardened pastes made from mixes (PPC-PPV) containing thermally treated PG at $600{ }^{\circ} \mathrm{C}$ after 3, 7, 28 and 90 days curing

Figure 9. Bulk density $\left(\mathrm{g} / \mathrm{cm}^{3}\right) \quad$ hardened pastes made from mixes (PPC-PPV) containing thermally treated PG at $800{ }^{\circ} \mathrm{C}$ after 3, 7, 28 and 90 days curing

Figure 10. Bulk density $\quad\left(\mathrm{g} / \mathrm{cm}^{3}\right)$ hardened pastes made from mixes (PPC-PPV) containing thermally treated PG at $1000{ }^{\circ} \mathrm{C}$ after 3, 7, 28 and 90 days curing
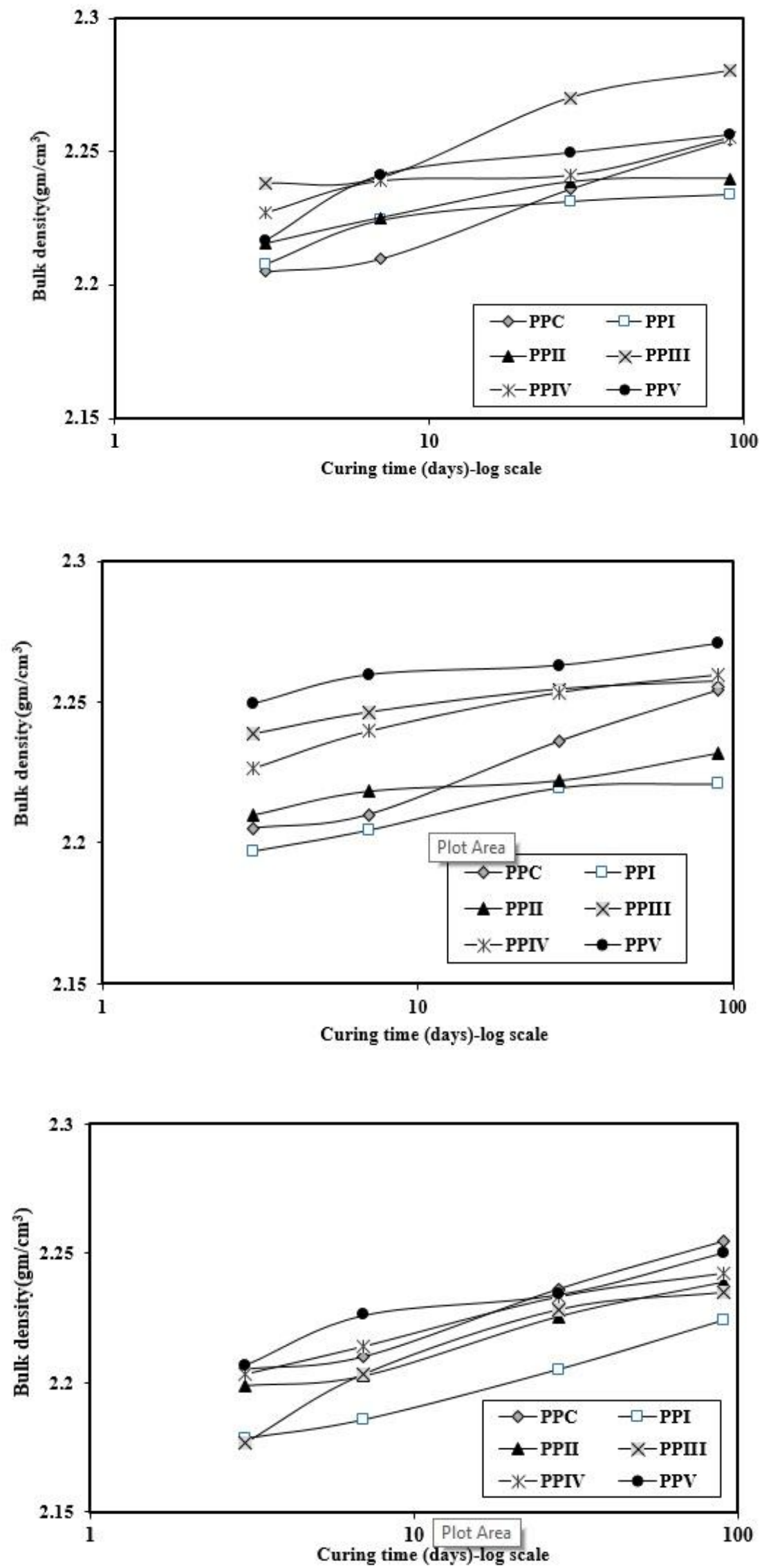
Figure 11. Porosity (\%) hardened pastes made from mixes (PPC-PPV) containing thermally treated $\mathrm{PG}$ at $200{ }^{\circ} \mathrm{C}$ after 3, 7, 28 and 90 days curing

Figure 12. Porosity (\%) hardened pastes made from mixes (PPI-PPV) containing thermally treated $\mathrm{PG}$ at $400{ }^{\circ} \mathrm{C}$ after $3,7,28$ and 90 days curing

Figure 13. Porosity (\%) hardened pastes made from mixes (PPC-PPV) containing thermally treated PG at $600{ }^{\circ} \mathrm{C}$ after $3,7,28$ and 90 days curing
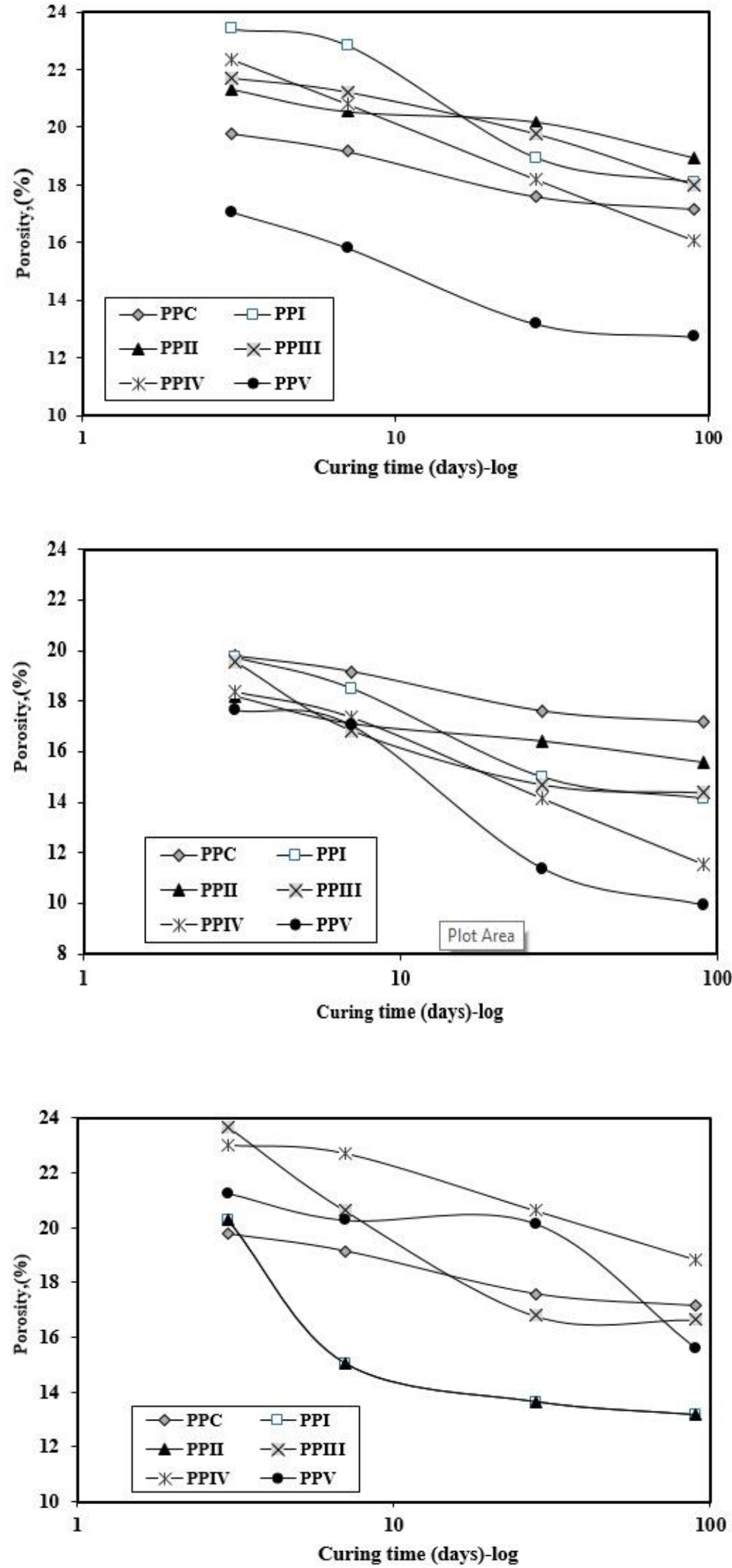
Figure 14. Porosity (\%) hardened pastes made from mixes (PPC-PPV) containing thermally treated $\mathrm{PG}$ at $800{ }^{\circ} \mathrm{C}$ after $3,7,28$ and 90 days curing

Figure 15. Porosity (\%) hardened pastes made from mixes (PPC-PPV) containing thermally treated PG at $1000{ }^{\circ} \mathrm{C}$ after $3,7,28$ and 90 days curing

Figure 16. Chemicallycombined water contents (Wn \%) hardened pastes made from mixes (PPC-PPV) containing thermally treated PG at $200^{\circ} \mathrm{C}$ after $3,7,28$ and 90 days curing
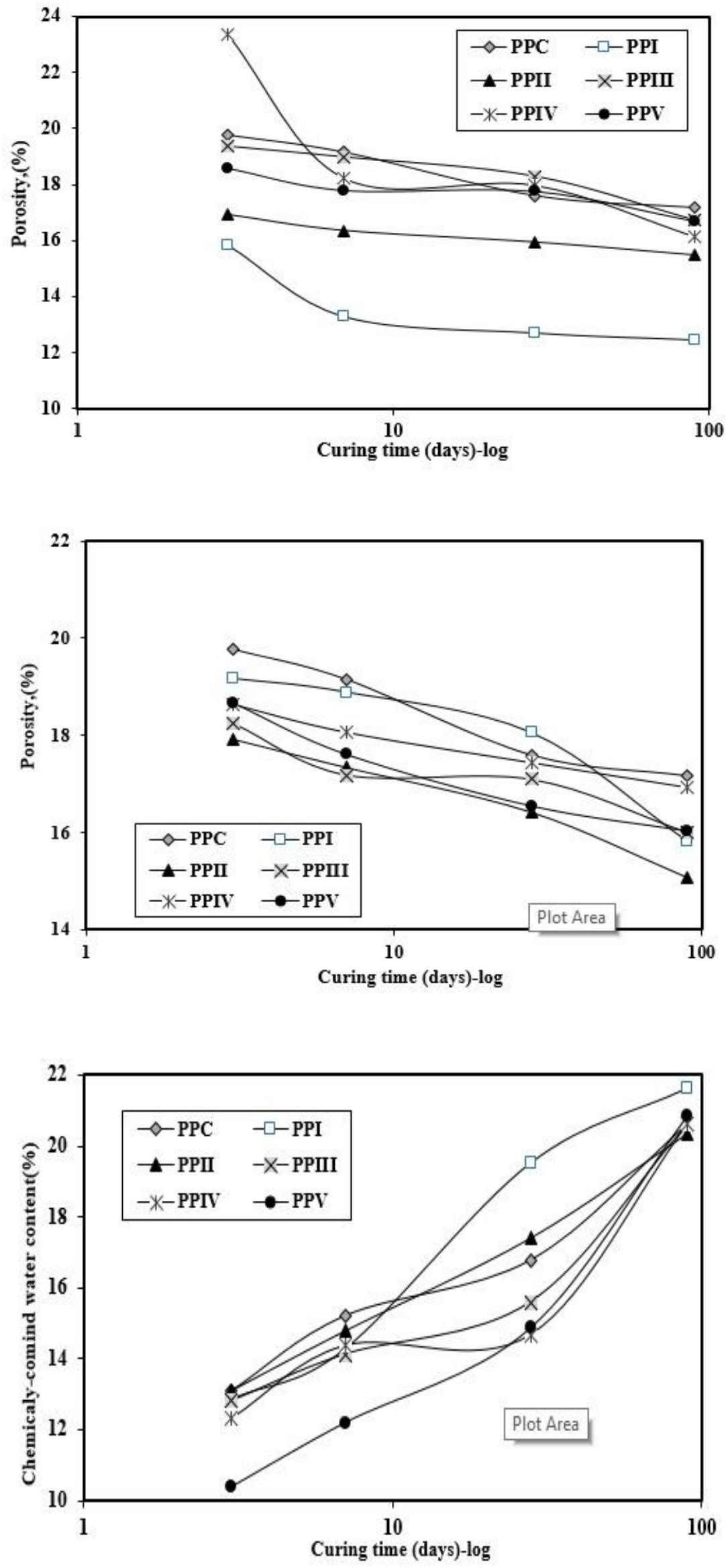
Figure 17. Chemicallycombined water contents (Wn \%) hardened pastes made from mixes (PPC-PPV) containing thermally treated PG at $400{ }^{\circ} \mathrm{C}$ after $3,7,28$ and 90 days curing

Figure 18. Chemicallycombined water contents (Wn \%) hardened pastes made from mixes (PPCPPV) containing thermally treated $P G$ at $600{ }^{\circ} \mathrm{C}$ after $3,7,28$ and 90 days curing

Figure 19. Chemicallycombined water contents (Wn \%) hardened pastes made from mixes (PPC-PPV) containing thermally treated $\mathrm{PG}$ at $800^{\circ} \mathrm{C}$ after $3,7,28$ and 90 days curing
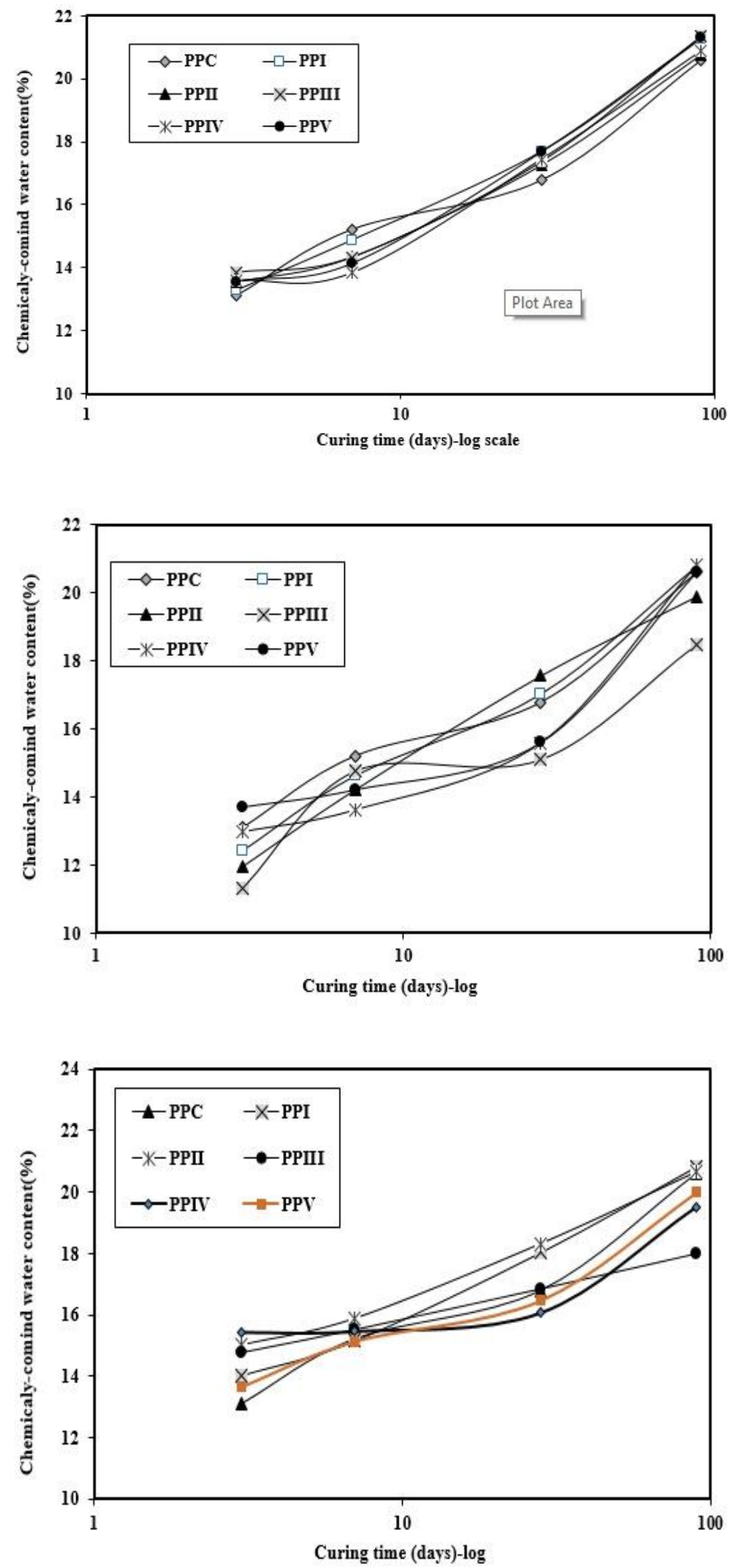
Figure 20. Chemicallycombined water contents (Wn \%) hardened pastes made from mixes (PPCPPV) containing thermally treated $\mathrm{PG}$ at $1000{ }^{\circ} \mathrm{C}$ after $3,7,28$ and 90 days curing

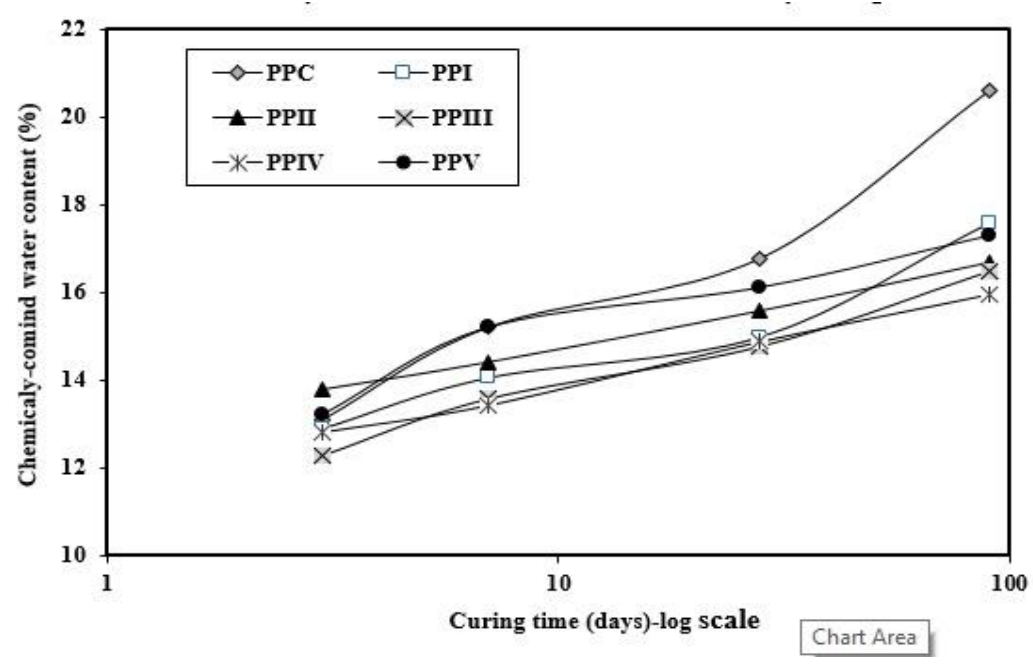

[32] and the weak intensity band at $470 \mathrm{~cm}^{-1}$ is attributed to $\mathrm{Si}-\mathrm{O}$ bending mode [33]. Figure 27 illustrated the IR spectra of hardened pastes of mix PPV contain PG thermally treated at $200{ }^{\circ} \mathrm{C}$ after 3,28 and 90 days curing. As hydration progresses, the following bands are observed the intensity of the band at $3650 \mathrm{~cm}^{-1}$ increases indicating liberation of more $\mathrm{Ca}(\mathrm{OH})_{2}$ the broad band at $3420 \mathrm{~cm}^{-1}$ are intensified with hydration, indicating that the increase of hydrated products associated with water and the strong asymmetric stretching Si-O band ( $v 3$ ) is shifted to high frequencies centered at $970 \mathrm{~cm}^{-1}$ with hydration indicates that the formation of C-S$\mathrm{H}$ [34]. The decrease and increase in intensities of the out-of-plane and in-plane Si$O$ bending vibrations are occur in significant changes with hydration and it indicates $\mathrm{SiO}_{4}{ }^{-}$ units in cement at $510 \mathrm{~cm}^{-1}$. The IR analysis of hardened pastes of mix PV contain PG treated at $600{ }^{\circ} \mathrm{C}$ after 3,28 and 90 days curing are shown in Figure 28 shows a sharp band at $3645 \mathrm{~cm}^{-1}$ associated to $\mathrm{O}-\mathrm{H}$ stretching vibrations of portlandite $\left(\mathrm{Ca}(\mathrm{OH})_{2}\right)$ and the peaks at 3420 and $1640 \mathrm{~cm}^{-1}$ are correspond to stretching and bending modes of water of crystallization particularly. The carbonates peak at $1470 \mathrm{~cm}^{-1}$ and $876 \mathrm{~cm}^{-1}$ are observed due to the reactions of atmospheric $\mathrm{CO}_{2}$ with calcium hydroxide. The broad band at $976 \mathrm{~cm}^{-}$ 1 is due to $\mathrm{Si}-\mathrm{O}$ asymmetric stretching 
vibration of C3S and/or C2S and very weak band at $465 \mathrm{~cm}^{-1}$ is attributed to Si-O bending mode [35]. As far as we are aware, spectroscopic of hardened pastes of mix PPV contain PG thermally treated at $1000{ }^{\circ} \mathrm{C}$ after
3, 28 and 90 days curing. Different bands appear at intensities $3644,3460,1655,1455$, 967,874 and $466 \mathrm{~cm}^{-1}$ which were illustrated before.
Figure 21. Free lime contents $(\mathrm{CaO} \%)$ hardened pastes made from mixes (PPI-PPV) containing thermally treated PG at $200{ }^{\circ} \mathrm{C}$ after $3,7,28$ and 90 days curing

Figure 22. Free lime contents $\quad(\mathrm{CaO} \quad \%)$ hardened pastes made from mixes (PPI-PPV) containing thermally treated $\mathrm{PG}$ at $400{ }^{\circ} \mathrm{C}$ after $3,7,28$ and 90 days curing

Figure 23. Free lime contents $\quad(\mathrm{CaO} \%)$ hardened pastes made from mixes (PPI-PPV) containing thermally treated PG at $600{ }^{\circ} \mathrm{C}$ after $3,7,28$ and 90 days curing
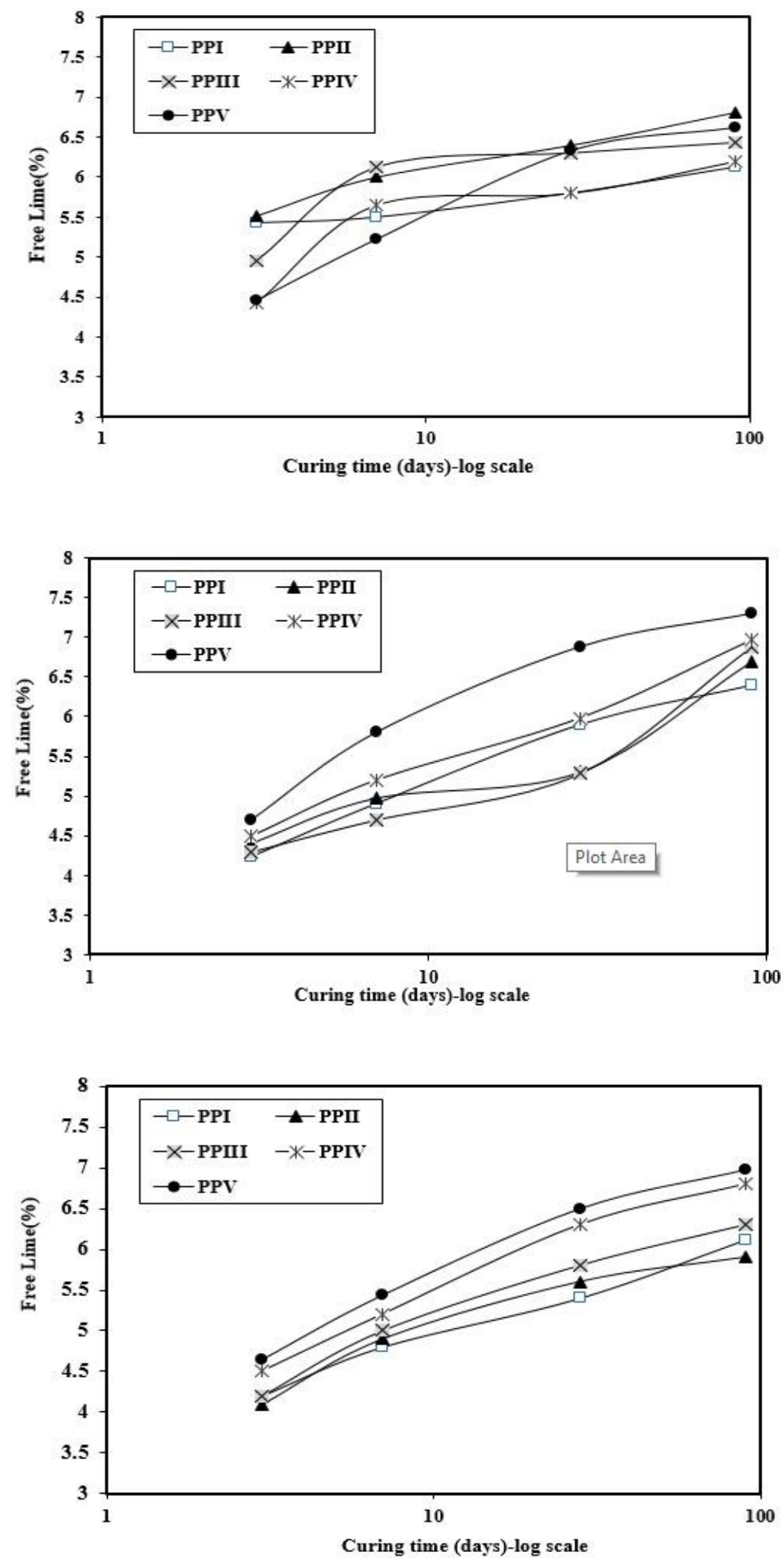
Figure 24. Free lime contents $(\mathrm{CaO} \%)$ hardened pastes made from mixes (PPI-PPV) containing thermally treated PG at $800{ }^{\circ} \mathrm{C}$ after 3, 7, 28 and 90 days curing

Figure 25. Free lime contents $(\mathrm{CaO} \%)$ hardened pastes made from mixes (PPI-PPV) containing thermally treated $\mathrm{PG}$ at $1000{ }^{\circ} \mathrm{C}$ after $3,7,28$ and 90 days curing

Figure 26. IR spectra of hardened pastes of PPC with RG after 3, 28 and 90 days curing
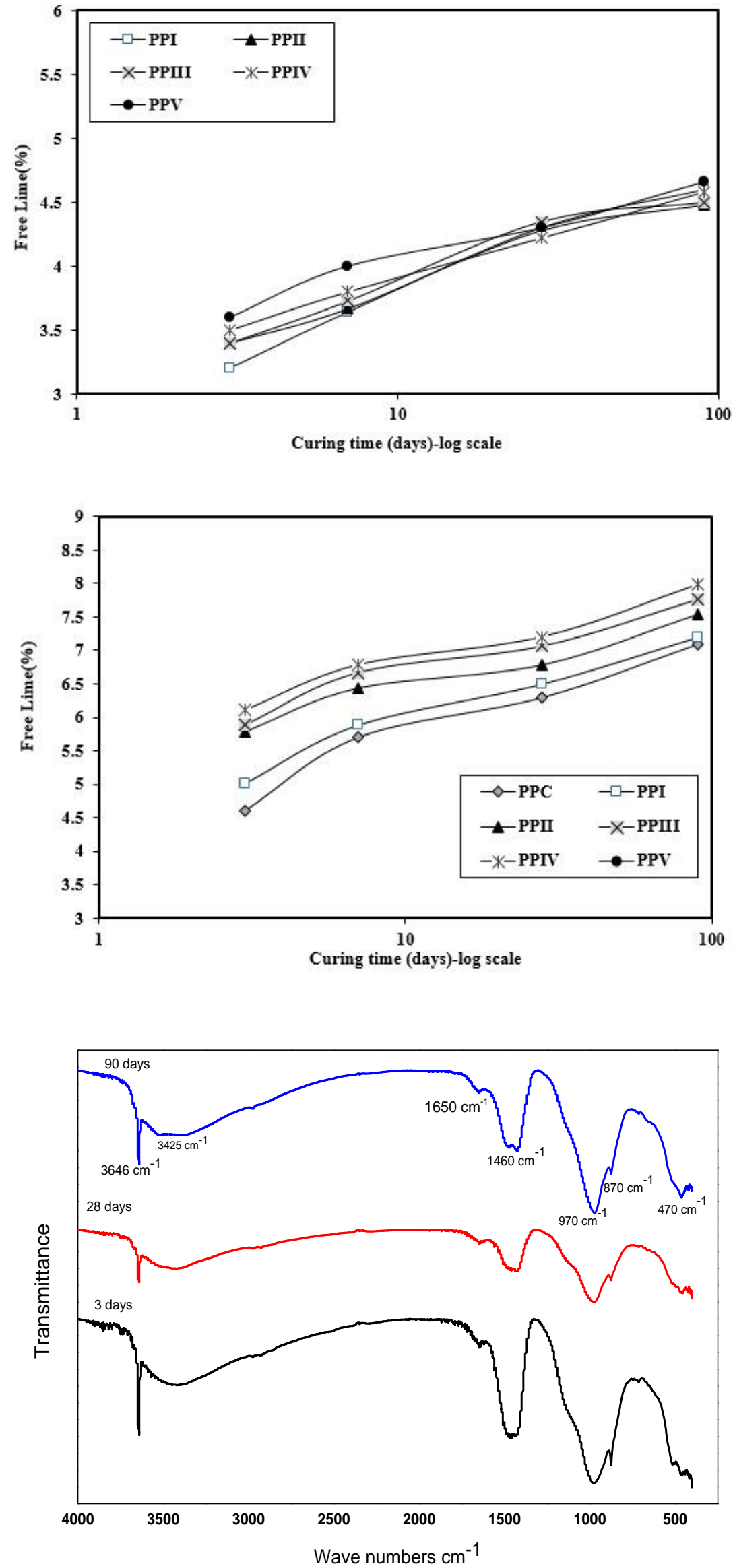
Figure 27. IR spectra of hardened pastes of mix PPC contain PG treated at $200{ }^{\circ} \mathrm{C}$ after 3, 28 and 90 days curing

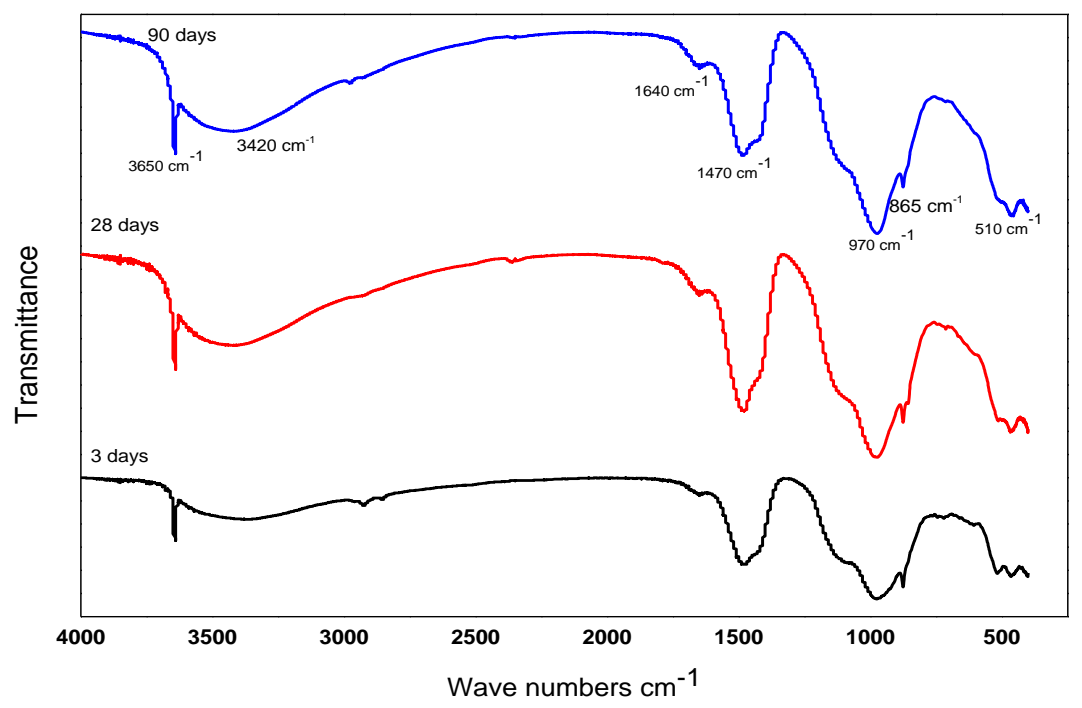

Figure 28. IR spectra of hardened pastes of mix PPC contain PG treated at $600{ }^{\circ} \mathrm{C}$ after 3,28 and 90 days curing

Figure 29. IR spectra of hardened pastes of mix PPC contain PG treated at $1000{ }^{\circ} \mathrm{C}$ after 3,28 and 90 days curing
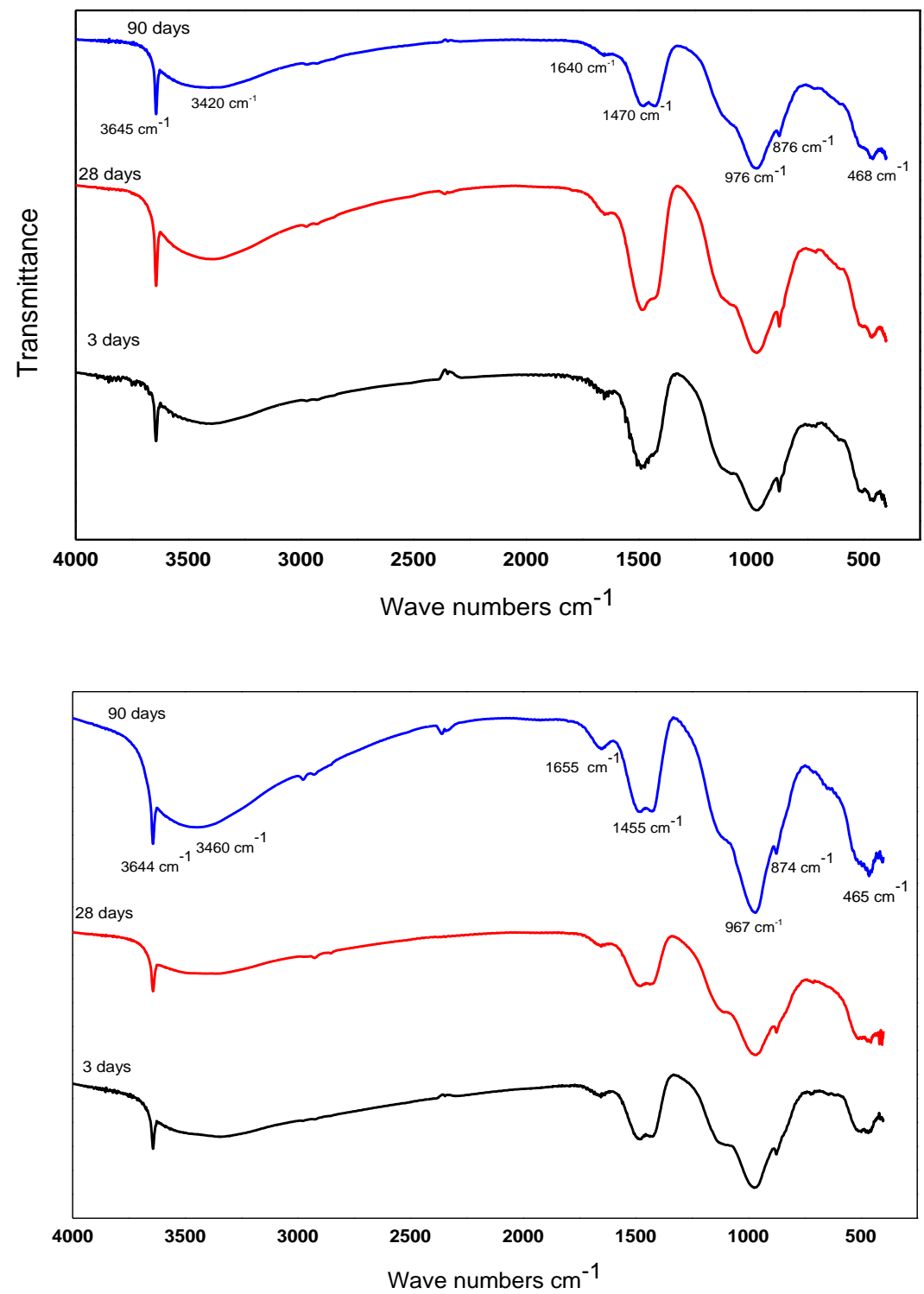


\section{Morphology and Microstructure}

The effect of thermally treated PG at different temperatures on the morphology and microstructure of prepared PPC pastes was analyzed under scanning electron microscope. Hardened specimens of mix PPV contain treated PG at 200,600 and $1000{ }^{\circ} \mathrm{C}$ after 3, 28 and 90 days curing, their SEM micrograph are shown in Figures 30-33. Figure $30 \mathrm{a}$ illustrated the micrograph of pastes contain raw gypsum and formation of various hydration products after 3 days a large amount of hexagonal $\mathrm{Ca}(\mathrm{OH})_{2}$ crystals and $\mathrm{C}-\mathrm{S}-\mathrm{H}$ are generated after the reaction of C3S with water. By continuous hydration process at Figure $30 \mathrm{~b}$ the micrograph indicated formation of more compact structure composed mainly of calcium silicate hydrates compared to the micrograph formation of amorphous hydrates and a massive structure of ill-crystallized CSH. The microstructure obtained after 90 days curing of PPC- RG, showed in Figure 30c a dense structure and more rode like of nearly amorphous $\mathrm{CSH}$ and ettringite $\left(\mathrm{C}_{3} \mathrm{~A} .3 \mathrm{CS} .32 \mathrm{H}_{2} \mathrm{O}\right)$ as representing the main hydration products. On the contract, hardened specimens of mix PPV contain treated PG at 200,600 and $1000{ }^{\circ} \mathrm{C}$ after 3, 28 and 90 days curing, their SEM micrograph are shown in Figures 31-33. The SEM micrographs displayed the formation of various hydration products after 3 days a large amount of $\mathrm{Ca}(\mathrm{OH})_{2}$ crystals are generated after the reaction of $\mathrm{C} 3 \mathrm{~S}$ with water, the generation of $\mathrm{Ca}(\mathrm{OH})_{2}$ and $\mathrm{C}-\mathrm{S}-\mathrm{H}$ was observed. These are generated from the chemical bonding involving $\mathrm{Ca}^{2+}$ around the C3S particle. The hydration microcrystalline crystals of monosulfate $\left(\mathrm{C}_{3} \mathrm{~A}\right.$.CS. $\left.12 \mathrm{H}_{2} \mathrm{O}\right)$ and some calcium silicate hydrates ( $\mathrm{CSH}$ ), fibrous crystals of ettringite $\left(\mathrm{C}_{3} \mathrm{~A} \cdot 3 \mathrm{CS} .32 \mathrm{H}_{2} \mathrm{O}\right)$ and Calcium hydroxide $\mathrm{Ca}(\mathrm{OH})_{2}$. By continuous hydration of the pastes PPC-PG after 28 days the ettringite crystals are much and leads to changes in the morphology of the surface from hexagonal shape to more ettringite crystals. At 90 days, the hydration is decreasing in the porosity and formation of amorphous and illcrystalline phase indication increases the hydraulic properties of the pastes which there is increasing in the amorphous and illcrystalline phase with formation of closed texture phase indication increases the hydraulic properties of the pastes. These results are in a good agreement with the obtained physico-chemical measurements of OPC-PG pastes [35].
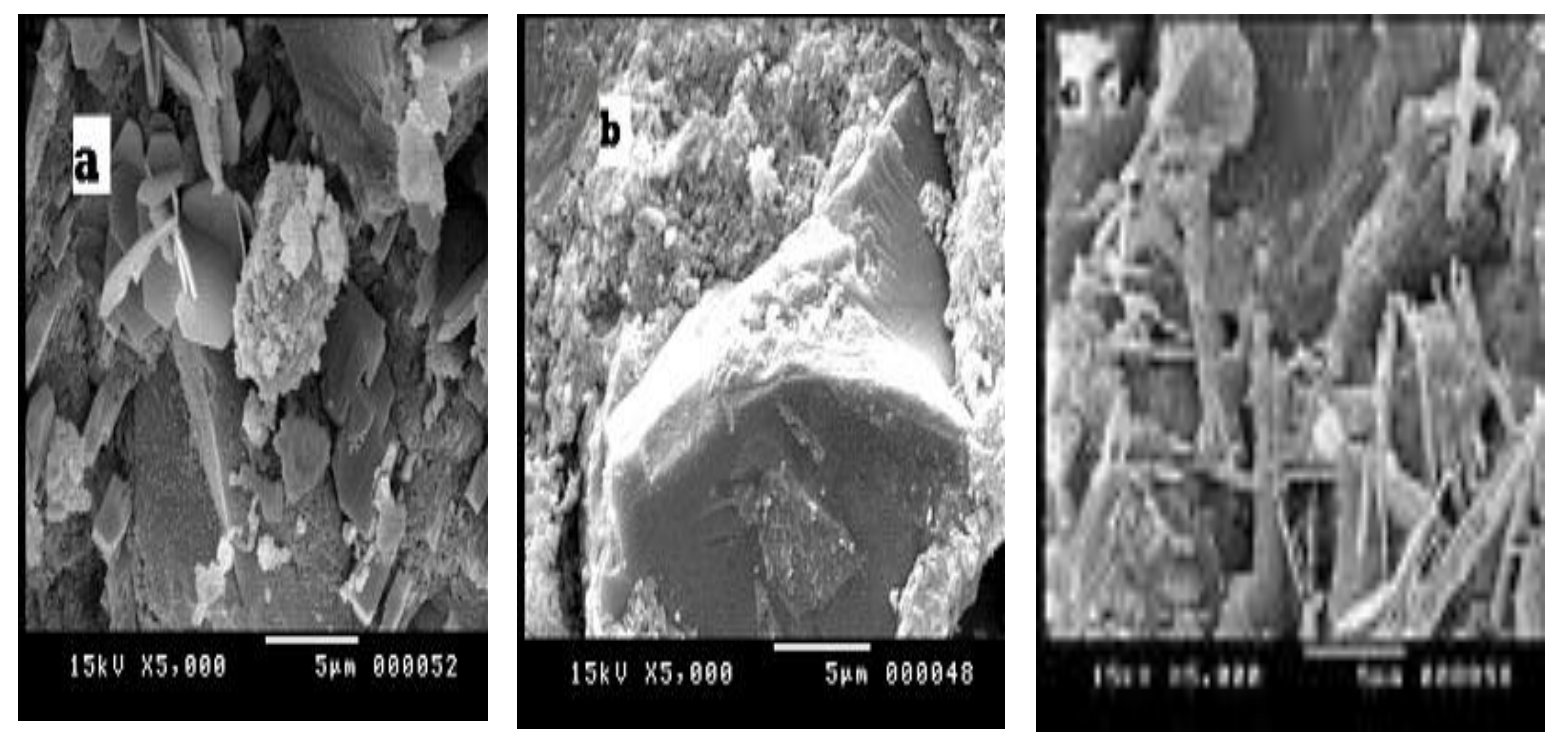

Figure 30. Micrographs of mixes (PPC) contain RG after 3 (a), 28 (b) and 90 (c) days curing 

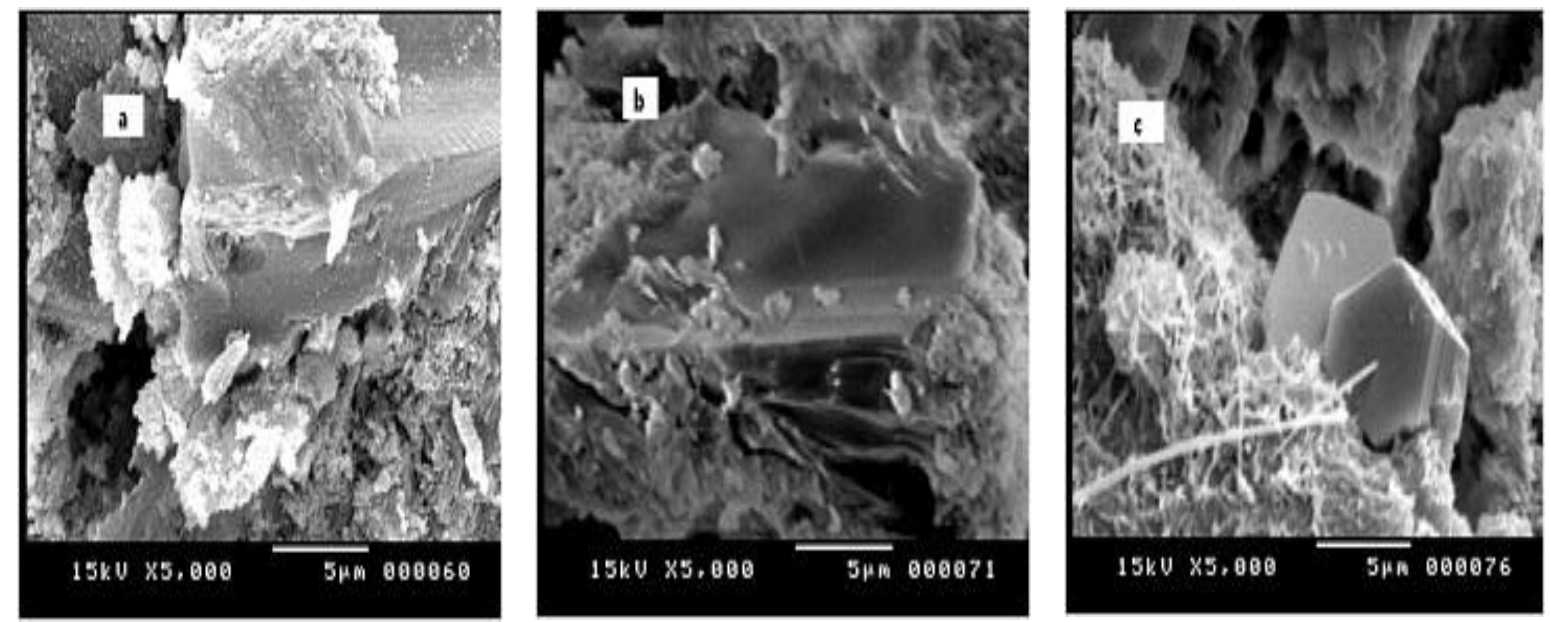

Figure 31. Micrographs of mixes (PPV) contain thermally treatment PG at $200{ }^{\circ} \mathrm{C}$ after $3(\mathrm{a})$, 28 (b) and 90 (c) days curing
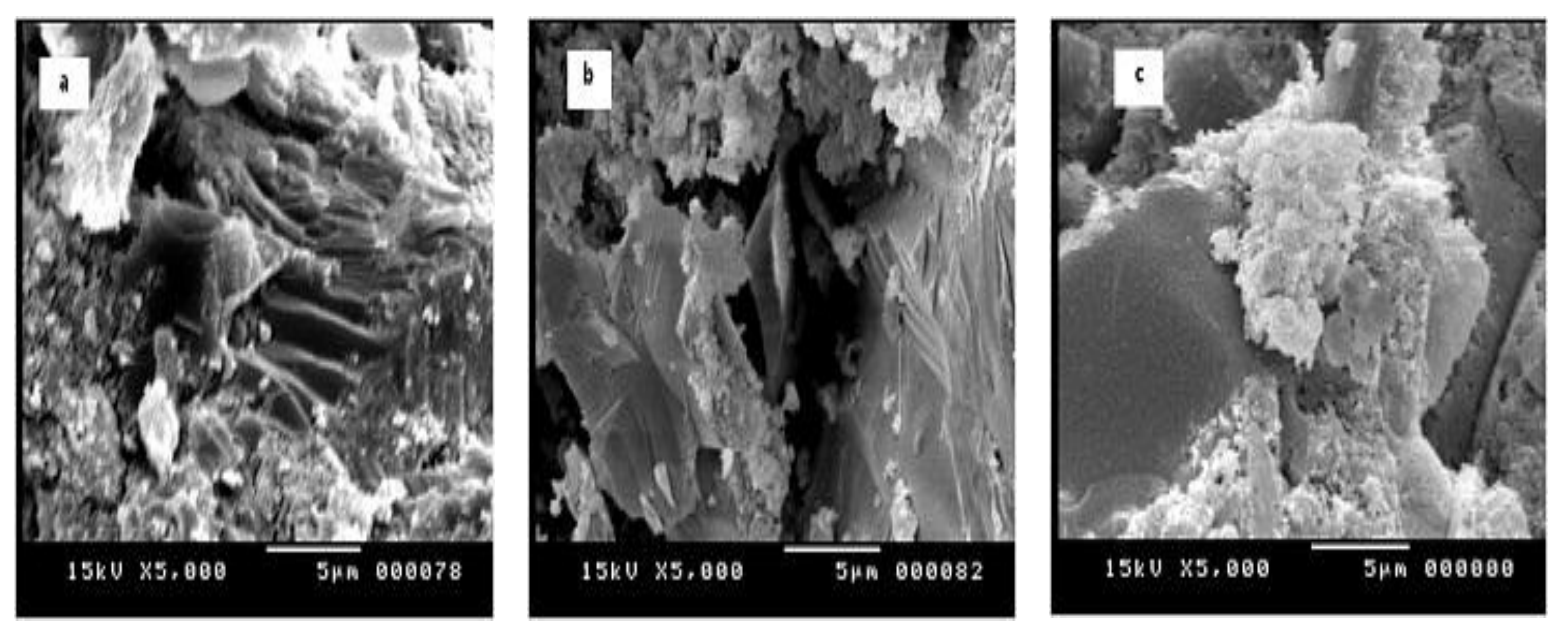

Figure 32. Micrographs of mixes (PPV) contain thermally treatment $P G$ at $600{ }^{\circ} \mathrm{C}$ after $3(\mathrm{a})$, 28 (b) and 90 (c) days curing
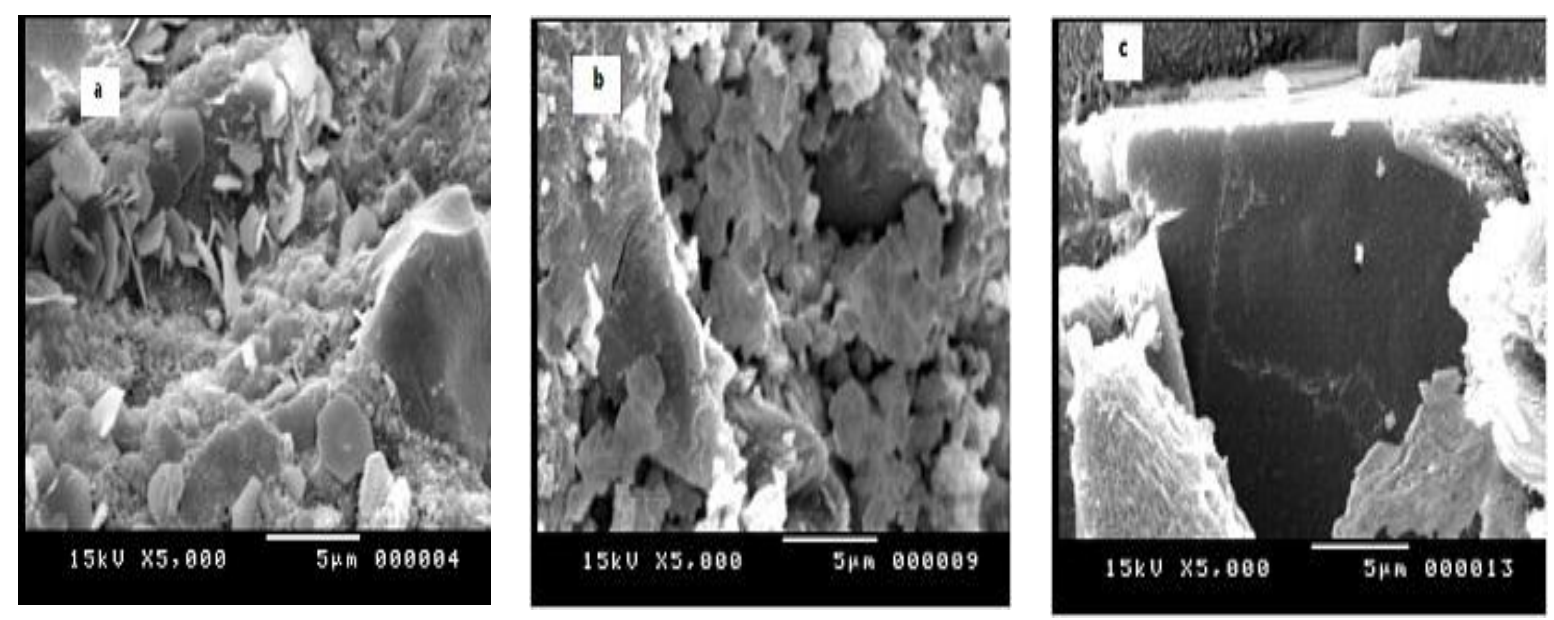

Figure 33. Micrographs of mixes (PPV) contain thermally treatment PG at $1000{ }^{\circ} \mathrm{C}$ after $3(\mathrm{a})$, 28 (b) and 90 (c) days curing 


\section{Conclusion}

As a measure to save resources and energy and reuse industrial byproducts in the cement industry, this study evaluated the basic properties of PPC using industrial byproducts. The results are as follows:

1-Phosphogypsum can be economically used up to five percent as an ingredient in Ordinary Portland cement, This will eliminate a serious environmental source of pollution; besides, it will decrease the cost of cement production. It is also recommended that further investigations be executed to explore the possibility of extracting gypsum from PG that can be used directly in cement industry.

2-The addition of treated PG at different temperature leading to improvement of physio-chemical properties.

3- The present study revealed a good efficiency of $P G$ as a set retarder in Pozzolanic Portland Cement, utilization calcined PG at 800 and $1000{ }^{\circ} \mathrm{C}$ causes the setting time improvement.

4-The purified phosphogypsum can be used for the production of gypsum in cement manufactory due to solve the serious negative environmental impacts caused by the dispersion of the harmful chemicals contained in PG into surrounding environment.

\section{Acknowledgment}

Thanks are due to the Manaseer Cement Factory for the execution of these experiments.

\section{References}

[1]. K. Friedhelm, K. Juergen, B. Marcel, Seminar on the utilization of phosphogypsum to produce cement and sulphuric acid, in: Proceedings, National Bureau and Veb Industrie-Consult Berlin, Istanbul - Turkey, 1987, p. 17.
[2]. A. Nanni, W.F. Chang, Concrete Int., 1989, 11, 48-53.

[3]. E. Erdem, H. Ölmez, Cem. Concr. Res., 1993, 23, 115-121.

[4]. J. Bijen, E. Niël, Cem. Concr. Res., 1981, 11, 307-322.

[5]. H. Ölmez, E. Erdem, Cem. Concr. Res., 1989, 19, 377-384.

[6]. H. Ölmez, V.T. Yilmaz, Cem. Concr. Res., 1988, 18, 449-454

[7]. D.K. Dutta, P.C. Borthakur, Cem. Concr. Res., 1990, 20, 711-722.

[8]. S. Al-Jabbari, F. Faisal, S. Ali, S. Nasir, J. Build. Res. Sci. Res. Council Baghdad, 1988, 7, 49-69.

[9]. H.F.W. Taylor, Cement Chemistry. Thomas Telford Edition, London, 1997, pp. 480.

[10]. M.M. Smadi, R.H. Haddad, A.M. Akour, Potential use of phosphogypsum in concrete", Cem. Concr. Res., 1999, 29, 1419 - 1425.

[11]. S. Manjit, Cem. Concr. Res., 2002, 32, 1033-1038.

[12]. S. Manjit. Cem. Concr. Res., 2003, 33, 1363-1369.

[13]. S. Manjit. Role of phosphogypsum impurities on strength and microstructure of selenite plaster." Construct. Build. Mater., 2005, 19, 480-486.

[14]. J.H. Potgieter, S.S. Potgieter, R.I. McCrindle, C.A. Strydom, Cem. Concr. Res., 2003, 33, 1223-1227.

[15]. L. Kacimi, A. Simon-Masseron, Z. Derriche, J. hazard. Mater., 2006, 137, 129137.

[16]. M.A. Bagade, S.R. Satone, Int. J. Eng. Res. Appl., 2012, 2, 785-787.

[17]. N. Ghafoori, W.F. Chang. J. Mater. Civil Eng., 1993, 5, 249-264.

[18]. K.T. Lin, W.F. Chang, Strength properties of compacted phosphogypsum-based mixtures, Volume II. In proceedings of the second International symposium on phosphogypsum, University of Miami, Florida Institute of Phosphate Research, Bartow, Florida, 1988, pp. 239-254.

[19]. M.A. Taher, Resources, Conservat. Recycl., 
2007, 52, 28-38.

[20]. T. Reddya, D. Siva Sankar, R. Kumarb, H. Sudarsana Raoc. Asian J. Civil Eng., 2010, 11, 411-420.

[21]. Z. M. Lan, X. J. Lin \& F. Wang \& H. Zhang \& C. R. Chen, Biol. Fertil. Soils, 2012, 48, 579588.

[22]. P.Y., Han, X.L., Jiao, Wang, L.G., Dong, E.W., J.S Wang, Chin. J. Eco Agric. 2010, 18, 482-485.

[23]. A. Roy, G.P. Byerly, R.K. Seals. J. Mater. Civil Eng., ASCE 6, 1994, 4, 439-445

[24]. British European Standard BS EN-196-3: Methods of testing cement. Determination of setting times and soundness, 2005.

[25]. M. Abd El Aziz, S. Abd El Aleem, M. Heikal, H. El Dizdamony, Cem. Concr. Res., 2005, 35, 1592-1600.

[26]. M.A.E. Aziz, S.A.E. Aleem, M. Heikal, H.E. Didamony, Cem. Concr. Res., 2005, 35, 15921600.

[27]. M.P. Javellana, I. Jawed. Cem. Concr. Res., 1982, 12, 399-403.

[28]. Z. Mingkai, S. Weiguo, W. Shaopeng, Z. Qinglin, Adv. Build. Technol., 2002, 1, 929-934. [29]. I.A. Altun, Y. Sert. Cem. Concr. Res., 2004, 34, 677-80.

[30]. M.N. De Noirfontaine, S. Tusseau-Nenez, M. Signes-Frehel, G. Gasecki, C. GirodLabianca. J. Am. Ceramic Soc., 2009, 92, 2337 2344.

[31]. F.A. Rodrigues P.J.M. Monteiro, J. Mater. Sci. Lett., 1999, 18, 1551-1552

[32]. W. Eitel, Silicate Science, Volume I: Silicate Structures, Academic Press, New York, NY, 1964, USA.

[33]. Y.M., Mollah, A., Palta, T.R., Hess, R.K., Vempati, D.L. Cocke, Cem. Concr. Res., 1995, 25, 671-682.

[34]. D. Govindarajan, R. Gopalakrishnan. Front. Sci., 2011, 1, 21-27

[35]. P. Meredith, A.M. Donald, N.Meller, C. Hall, J. Mater. Sci., 2004, 39, 997-100.
How to cite this manuscript: Mahmoud. A. Taher, Adel. M. Amine, Bassam Kh. Damarany*. Effect of Partial Substitution of Raw Gypsum with Thermally Treated Phosphogypsum on the Properties of Portland Pozzolanic Cement, Adv. J. Chem. A, 2019, 2(4), 296315. 